\title{
Oral Manifestations among Diabetic Patients: A Cross-Sectional Study
}

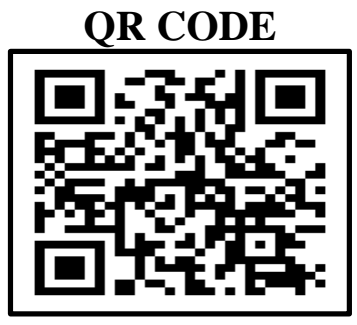

\section{PREETI AGNIHOTRI', (D YASHIKA SHARMA² (D)}

INTRODUCTION: Diabetes, ranked as the ninth most common disorder has the potential to greatly affect the oral health of a person if not taken care of on a routine basis.

AIM: To assess the prevalence of oral manifestations in diabetic participants of Sunder Nagar town, Himachal Pradesh, India.

MATERIALS AND METHOD: This online, questionnaire based cross-sectional study was conducted using a combination of convenience and snowball sampling among diabetics. The questionnaire was pre-tested and pre-validated, contained 16 questions which included self-reported oral health status of the people. The student's t-test and Pearson's correlation were applied to find out significant associations, if any. Data was analysed using SPSS version 21.0 and significance (p) was kept significant at $\leq 0.05$.

RESULTS: Out of a total of 180 complete responses, $8.3 \%$ were type 1 diabetics, $72.8 \%$ were type 2 diabetics and the rest $18.9 \%$ didn't know their diabetic status. $71.7 \%$ of patients experienced bad breath, out of which $66.7 \%$ experience it early in the morning, $16.1 \%$ during the daytime, $5 \%$ every time, $12.2 \%$ never $(\mathrm{p}=\mathbf{0 . 0 2}) \cdot \mathbf{2 4 . 4 \%}$ of the participants experienced burning mouth sensation, while $57.8 \%$ of participants experienced dry mouth (less salivation). $20.6 \%$ of the participants reported white patches over their tongue while $8.3 \%$ reported having white patches over the inner cheeks (buccal mucosa) and was found to be statistically significant $(\mathrm{p}=0.01) .58 .9 \%$ of the diabetics were found to be non-smokers while $21.7 \%$ were occasional smokers and $11.1 \%$ were chain smokers.

CONCLUSION: There is a need to educate diabetics regarding the effects of this disease on their oral health and the need to maintain proper hygiene.

\section{INTRODUCTION}

Humankind has always tried to emphasize on the fact that "the greatest wealth is health". This is further strengthened by the definition of health by the World Health Organization (WHO), which states that "Health is a state of complete physical, mental, and social well-being and not merely the absence of disease or infirmity." Over the last several decades, our diets have become unhealthy, our lifestyles sedentary and many of us still use tobacco and abuse alcohol which has resulted in an ever-increasing prevalence of lifestyle diseases. As per WHO estimates, Noncommunicable Diseases (NCDs) kill 41 million people each year, which is equivalent to $71 \%$ of all deaths globally. Among these NCDs, one such disease is diabetes which is ranked as the ninth most common disorder amassing a 68\% increase between 1990 to 2010.

Experts believe that between the years 2010 and 2030, the number of adults with Diabetes Mellitus (DM) in developing countries is expected to increase by a whopping $69 \% .{ }^{1}$ Diabetes is a major cause of blindness, kidney failure, heart attacks, stroke and lower limb amputation. According to WHO, in the year 2019, diabetes was the ninth leading cause of death causing an estimated 1.5 million deaths as a result of this disease. ${ }^{2-4}$

Diabetes is a chronic, metabolic disease characterized by elevated levels of blood glucose (or blood sugar).Two main types Type 1 diabetes (Lack of insulin) and Type 2 diabetes (ineffective insulin). ${ }^{1}$ According to WHO, 422 million people worldwide have diabetes, particularly in low-and middle-income countries and Diabetes is one of the leading causes of death. ${ }^{5} \mathrm{~A}$ healthy diet, regular physical activity, maintaining a normal body weight and avoiding tobacco use are ways to prevent or delay the onset of type 2 diabetes. It can be treated and its consequences avoided or delayed with the aid to proper diet, regular physical activity, medication and regular screening for complications at regular intervals. Diabetics who smoke are at an even higher risk, of up to 20 times to develop thrush and periodontal disease as compared to their non-smoking counterparts. Among diabetics, smoking has been found to impair blood flow to the gums, thus affecting 
wound healing in this tissue area. ${ }^{6}$

Oral health has been identified as a key indicator of one's overall health, general well-being and assessing one's quality of life. As per the Global Burden of Disease Study (2017), oral diseases has been found to affect 3.5 billion people across the globe., ${ }^{1,2,6}$ The International Agency for Research on Cancer, has reported that cancers pertaining to the lip and oral cavity are among the top 15 most common cancers, with nearly 180,000 deaths each year across the world. ${ }^{6,7}$ It is a welldocumented fact that most oral diseases and conditions share alterable risk factors with leading noncommunicable diseases and a variety of oral health conditions are largely preventable and can be treated in their early stages through proper screening or regular dental check-ups.

As per scientific evidence, the oral manifestations are among diabetics ranges from periodontal diseases, caries/periapical periodontitis, tooth loss, periimplantitis, dry mouth (xerostomia), candidiasis, taste disturbances, burning mouth syndrome and cancer., ${ }^{8,9}$ Due to a paucity of data, the present study was carried out with the aim to assess the prevalence of oral manifestations in diabetic participants of Sunder Nagar town, Himachal Pradesh, India.

\section{MATERIALS AND METHOD}

An online, cross-sectional study was conducted on diabetic participants of Sunder Nagar town through a combination of convenience and snowball sampling. The study was conducted for a period of one month in the month of July, 2021. Data was collected using a pretested and pre-validated questionnaire containing 16 questions which included self-reported oral health status of the people. The questionnaire was available in both Hindi and English languages, and willing participants were first directed to a page explaining the study objectives as well as a button, which upon clicking signified their consent to participate in the study. A pilot study was conducted amongst fifteen subjects to validate the questionnaires and make subsequent adjustments. The data of these subjects was analysed with the main study participants and not included in the final analysis.

Participants were free to leave the questionnaire in between and only complete responses were accepted for analysis. Upon submission of the form, if a participant failed to answer $\geq 1$ question(s) it was removed from the analysis.
Data was tabulated and the student's t-test and Pearson's correlation were applied to find out significant associations, if any. Data was analysed using SPSS version 21.0 and significance (p) was kept significant at $\leq 0.05$.

\section{RESULTS}

The age and diabetic status of the participants is depicted in table 1 . Out of a total of 180 complete responses, $7.18 \%$ were above 15 years and below 39 years, $72.38 \%$ were above 40 years and below 63 years and the rest $19.89 \%$ were above 64 years and below 81 years. Out of these 180 participants, $8.3 \%$ were Type 1 diabetic, $72.8 \%$ were Type 2 diabetic and the rest $18.9 \%$ didn't know their diabetic status.

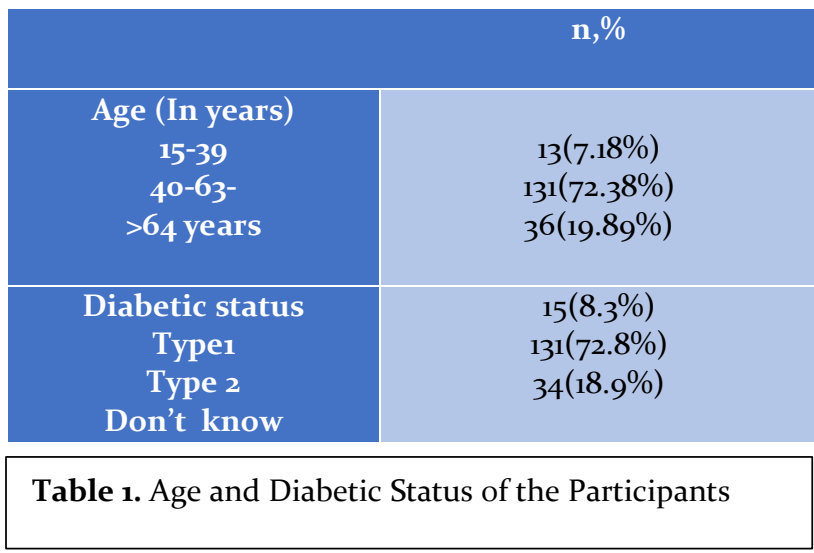

Table 2 reveals the self-reported oral manifestations of the participants. It was reported that $71.7 \%$ of participants experienced bad breath, out of which $66.7 \%$ experience it early in the morning, $16.1 \%$ during the daytime, $5 \%$ every time, $12.2 \%$ never and the difference was found to be significant $(\mathrm{p}=\mathrm{0.02})$. A total of $24.4 \%$ of the participants experienced burning mouth sensation, while $57.8 \%$ of participants experienced dry mouth (less salivation). Among these participants, $20.6 \%$ had white patches over their tongue while $8.3 \%$ reported having white patches over the inner cheeks (buccal mucosa), which was found to be statistically significant $(\mathrm{p}=0.01)$.

Table 3 reveals the self-reported dental health of the participants, and it was found that $20 \%$ out of them reported having swollen gums while $23.9 \%$ experienced it sometimes. A majority of the participants (70.5\%) had a teeth count ranging from 23 to $32.45 \%$ of participants had good oral hygiene and didn't experience any pain while eating, drinking, and 


\begin{tabular}{|c|c|c|c|c|c|}
\hline \multirow{2}{*}{$\begin{array}{c}\text { Oral } \\
\text { Manifestations } \\
\text { Bad breath } \\
\text { If yes, when }\end{array}$} & \multicolumn{4}{|c|}{ Responses } & p-value \\
\hline & $\begin{array}{c}\text { Yes- } 129(71.7 \%) \\
\text { Early morning- } 86 \\
(66.7 \%) \\
\text { Daytime- } 20(16.1 \%) \\
\text { Every time- } 7(5 \%) \\
\text { Never- } 16(12.2 \%)\end{array}$ & $\begin{array}{c}\text { No- } \\
22(12.2 \%)\end{array}$ & $\begin{array}{c}\text { Sometimes- } \\
27(15 \%)\end{array}$ & Never-2( $1 \%)$ & $0.02^{*}$ \\
\hline $\begin{array}{l}\text { Burning mouth } \\
\text { Sensation }\end{array}$ & Yes- $44(24.4 \%$ & $\begin{array}{c}\text { No- } \\
90(49.4 \%)\end{array}$ & $\begin{array}{c}\text { Sometimes- } \\
44(24 \cdot 4 \%)\end{array}$ & $\begin{array}{l}\text { I don't know- } \\
2(1 \%)\end{array}$ & 0.08 \\
\hline $\begin{array}{c}\text { Dry mouth } \\
\text { (less salivation) } \\
\end{array}$ & Yes- $105(57.8 \%)$ & $\begin{array}{c}\text { No- } \\
40(22.2 \%)\end{array}$ & $\begin{array}{c}\text { Sometimes- } \\
33(18.3 \%)\end{array}$ & $\begin{array}{l}\text { I don't know- } \\
2(1 \%)\end{array}$ & 0.05 \\
\hline $\begin{array}{c}\text { White patches over } \\
\text { Tongue }\end{array}$ & Yes- $37(20.6 \%)$ & $\begin{array}{l}\text { No- } 122 \\
(67.8 \%)\end{array}$ & $\begin{array}{l}\text { Maybe- } \\
15(8.3 \%)\end{array}$ & $\begin{array}{c}\text { I don't know - } \\
6(3.3 \%)\end{array}$ & 0.87 \\
\hline $\begin{array}{l}\text { White patches over } \\
\text { Inner cheeks }\end{array}$ & Yes- $15(8.3 \%)$ & $\begin{array}{c}\text { No- } \\
142(78.9 \%)\end{array}$ & $\begin{array}{l}\text { Maybe- } \\
11(6.1 \%)\end{array}$ & $\begin{array}{l}\text { I don't know- } \\
12(6.7 \%)\end{array}$ & $0.01^{*}$ \\
\hline
\end{tabular}

Table 2. Self-Reported Oral Manifestations of the Participants

brushing, while $17.8 \%$ did so. A total of $21 \%$ of participantsexperienced sensitivity while eating/drinking and brushing, while $27.2 \%$ of participants experienced intermittently bleeding from the gingiva. Upon statistical analysis, none of the responses were found to be statistically significant.

Habits of the participants in relation to smoking and alcohol consumption is depicted in table 4 , and it was observed that $58.9 \%$ were non-smokers, $21.7 \%$ were occasional smokers and $11.1 \%$ were chain smokers, while $60 \%$ of the respondents reported never drinking alcohol.

Table 5 reveals the self-reported oral hygiene practices of the participants. Regarding their dental check-up status, $43.3 \%$ were regular visitors, while $37.2 \%$ of participants had 'never visited' a dental facility. The relationship between oral hygiene practices and dental visit status was found to statistically significant $(\mathrm{p}=0.01)$.

Analysis of relationship between diabetes and other variables using the Pearson's correlation coefficient revealed a positive, linear relationship with the scores of oral manifestation $(\mathrm{r}:+0.66, \mathrm{p}=0.02)$ and oral hygiene (table 6).

\section{DISCUSSION}

Based on the results of the present study, it can be concluded that over half of the participants have

\begin{tabular}{|c|c|c|c|c|c|}
\hline Self-Reported & \multicolumn{4}{|c|}{ Responses } & \multirow{2}{*}{$\begin{array}{c}\text { P value } \\
0.66\end{array}$} \\
\hline Swollen gums & Yes- $36(20 \%)$ & No- $97(53.9 \%)$ & $\begin{array}{c}\text { Sometimes- } \\
43(23.9 \%)\end{array}$ & $\begin{array}{c}\text { Every time- } \\
4(2.2 \%)\end{array}$ & \\
\hline $\begin{array}{l}\text { Total number of } \\
\text { Teeth present }\end{array}$ & $(0-10)-25(13.73 \%)$ & $(11-22)-28(15 \cdot 5 \%)$ & $\begin{array}{c}(23-32)- \\
127(70.5 \%)\end{array}$ & & 0.76 \\
\hline Pain in gums/teeth & $\begin{array}{c}\text { While } \\
\text { eating/drinking- } \\
32(17.8 \%)\end{array}$ & $\begin{array}{l}\text { While brushing- } \\
\text { 32(17.8\%) }\end{array}$ & Both- 35(19.4\%) & None- $81(45 \%)$ & 0.65 \\
\hline $\begin{array}{l}\text { Sensitivity in } \\
\text { gums/teeth }\end{array}$ & $\begin{array}{c}\text { While } \\
\text { eating/drinking- } \\
42(23 \cdot 3 \%)\end{array}$ & $\begin{array}{c}\text { While brushing- } \\
\text { 30(16.7\%) }\end{array}$ & Both- 38(21.1\%) & $\begin{array}{c}\text { None- } \\
70(38.9 \%)\end{array}$ & 0.88 \\
\hline Bleeding gums & Yes- $27(15 \%)$ & No- $99(55 \%)$ & $\begin{array}{c}\text { Sometimes- } \\
49(27.2 \%)\end{array}$ & $\begin{array}{c}\text { Every time- } \\
5(2.8 \%)\end{array}$ & 0.87 \\
\hline
\end{tabular}

Table 3. Self-Reported Dental Health of the Participants 


\begin{tabular}{|c|c|c|c|c|}
\hline \multicolumn{5}{|l|}{ Habits } \\
\hline $\begin{array}{c}\text { Smoke } \\
\text { cigarettes/ } \\
\text { tobacco } \\
\end{array}$ & $\begin{array}{c}\text { Daily- } \\
20(11.1 \%)\end{array}$ & $\begin{array}{c}\text { Occasionally- } \\
40(21.7 \%)\end{array}$ & $\begin{array}{l}\text { Never- } \\
105, \\
(58.9 \%)\end{array}$ & $\begin{array}{l}\text { Stopped- } \\
15,(8.3 \%)\end{array}$ \\
\hline $\begin{array}{c}\text { Drink } \\
\text { alcohol }\end{array}$ & $\begin{array}{c}\text { Daily- } \\
8(4.15 \%)\end{array}$ & $\begin{array}{c}\text { Occasionally- } \\
57(31.7 \%)\end{array}$ & $\begin{array}{l}\text { Never- } \\
108,(60 \%)\end{array}$ & $\begin{array}{l}\text { Stopped- } \\
7,(4.15 \%)\end{array}$ \\
\hline
\end{tabular}

Table 4. Habits of the Participants in Relation to Smoking and Alcohol Consumption

practices found to be statistically adequate oral health knowledge related to diabetes.

While reporting their oral manifestations, $71.7 \%$ of participants experienced bad breath, out of which $66.7 \%$ experienced it early in the morning, while $16.1 \%$ experienced it during the daytime, $5 \%$ experiencing it every time, and $\mathbf{1 2 . 2} \%$ never reported having bad breath. These findings are higher as compared to a study where halitosis was reported only in $23.3 \%$ of their diabetic patients. ${ }^{10,11}$ Modification in diet is often advised for participants with diabetes to prevent these and other symptoms associated with diabetes as the restricted consumption of carbohydrates may have a non-cariogenic effect as it has been reported that the anti-microbial defence capacity of saliva is not weakened in diabetes. ${ }^{2,3,9}$

Self-reported dental examination revealed a prevalence of swollen gums in $20 \%(36)$ among the participants, with $23.9 \%$ of them experiencing it sometimes, while $27.2 \%$ of the participants experience $d$ intermittent bleeding from their gingiva. These findings are in agreement to Bissong $\mathrm{M}$ et al, who reported $23.5 \%$ of their diabetic patients suffering from. Overall in their study, gingivitis, periodontitis and oral candidiasis was significantly higher in diabetics as compare to their non-diabetic counterparts. ${ }^{12}$ An encouraging fact was that $45 \%$ of the participants with good oral hygiene didn't experience any pain while eating, drinking, and brushing.

In the present study, $58.9 \%$ of the diabetics were found to be non-smokers with $21.7 \%$ of them being occasional are in agreement to Thresia CU et al. ${ }^{13}$, who reported that a significant proportion (59\%) of diabetes patients in their study were tobacco consumers prior to their diagnosis and alarmingly, more than half of them continued to use tobacco on a daily basis even after their diagnosis.

Oral health care is conventionally disease-oriented, curative, and serves limited people due to high costs. Given the burden of unmet dental care needs and their association with systemic conditions, it is propagated that these services should primarily be based on education to increase awareness and influence the attitude of the people in seeking oral health care. Our study is among the few studies in its region to have followed a comprehensive approach by integrating oral health with NCDs. ${ }^{10,12}$

This study is prone to certain limitations. The first being the self-reported nature of the data collected, however, keeping the pandemic in mind, patients might be apprehensive to get their oral screening done. The second limitation being the inadvertent over/under reporting of information by respondents. To counter this, no personal data was collected by the participants and hence, the results of the present study can be generalized.

\section{CONCLUSION}

Based on the results, it can be concluded that there is a need to educate diabetics regarding the effects of this disease on their oral health and the need to maintain proper hygiene. This can be achieved through individual patient care among those visiting dental clinics for treatment or through various community based programmes.

\section{REFERENCES}

1. Shaw JE, Sicree RA, Zimmet PZ. Global estimates of the prevalence of diabetes for 2010 and 2030. Diabetes Research and Clinical Practice. 2010;87:4-14. https://doi.org/10.1016/j.diabres.2009.10.007

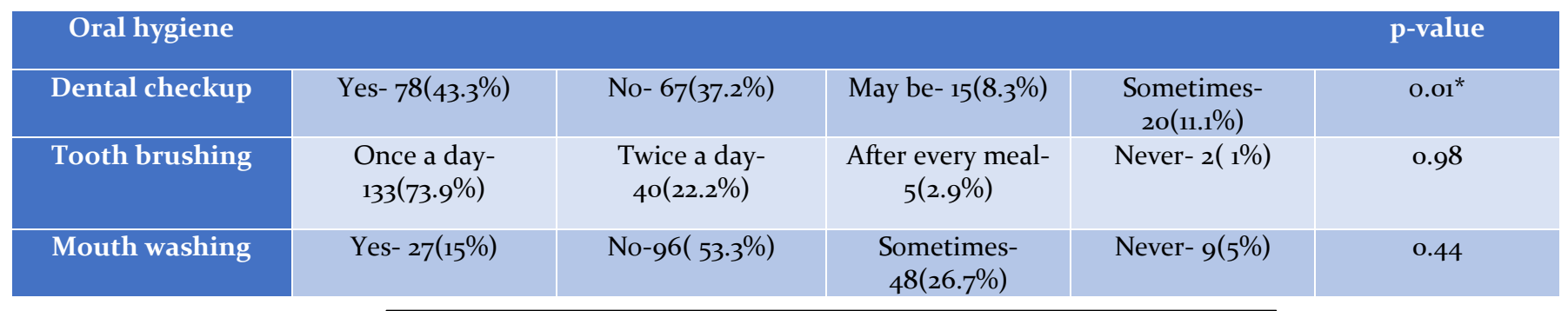

Table 5. Self-Reported Oral Hygiene Practices of the Participants 


\begin{tabular}{|c|c|c|}
\hline $\begin{array}{c}\text { Relationship } \\
\text { between diabetes } \\
\text { and }\end{array}$ & r value & p-value \\
\hline Age & +0.54 & 0.34 \\
\hline $\begin{array}{c}\text { Oral } \\
\text { Manifestations }\end{array}$ & +0.66 & $0.02^{*}$ \\
\hline Dental Health & +0.23 & 0.98 \\
\hline Habits & +0.77 & 0.78 \\
\hline $\begin{array}{c}\text { Oral hygiene } \\
\text { practices }\end{array}$ & +0.46 & $0.01^{*}$ \\
\hline
\end{tabular}

Table 6. Analysis of relationship between diabetes and other variables using the Pearson's correlation coefficient

2. Vos T, Flaxman AD, Naghavi M, Lozano R, Michaud C, Ezzati M, et al. Years lived with disability (YLDs) for 1160 sequelae of 289 diseases and injuries 1990-2010: a systematic analysis for the Global Burden of Disease Study 2010. Lancet. 2012;380(9859):2163-96. https://doi.org/10.1016/So140-6736(12)61729-2.

3. Bajaj S, Prasad S, Gupta A, Singh VB. Oral manifestations in type-2 diabetes and related complications. Indian J Endocrinol Metab [Internet]. 2012;16(5):777-9.

4. American Diabetes Association. Report of the expert Committee on the diagnoses and classification of diabetes mellitus. Diabetes Care 1997;20:1183-97.

5. World Health Association (WHO). Diabetes. (Online Article). Available from: https://www.who.int/newsroom/fact-

sheets/detail/diabetes\#: :text=The\%2onumber\%20of\% 2opeople\%2owith,stroke\%2oand\%2olower\%2olimb\%20 amputation. [Last Accessed on $12^{\text {th }}$ November, 2021]

6. Ministry of Health and Family Welfare. Prevention screening and control of common Non-Communicable Diseases: Hypertension, Diabetes and Common
Cancers (Oral, Breast and Cervix). 2016. (Online PDF) Available from: http://nicpr.res.in/images/PDF/guidelines for populat ion level screening of common NCDs.pdf. [Last Accessed on $12^{\text {th }}$ November, 2021]

7. American Diabetes Association. Report of the expert Committee on the diagnoses and classification of diabetes mellitus. Diabetes Care. 1997;20:1183-97.

8. Genco RJ. Assessment of risk of periodontal disease. Compend Suppl. 1994;(18):S678-83.

9. Al-Khabbaz AK, Al-Shammari KF, Al-Saleh NA. Knowledge about the association between periodontal diseases and diabetes mellitus: contrasting dentists and physicians. J Periodontol. 2011;82:360-6. https://doi.org/10.1902/jop.2010.100372.

10. Ravindran R, Deepa MG, Sruthi AK, et al. Evaluation of oral health in type II diabetes mellitus patients. Oral Maxillofac Path J. 2015;6(1):525-31. https://doi.org/10.5005/10037-1030

11. Nada A, Abdel Moneim W, Fakhr M, El Sawy S. Prevalence of Burning Mouth Syndrome in A sample of Egyptian Patients with Diabetic Neuropathy: A Cross Sectional Hospital-Based Study. Advanced Dental Journal 2020;2(2):34-42. https://doi.org/10.216o8/adjc.2020.23213.1050

12. Bissong M, Azodo CC, Agbor MA, Nkuo-Akenji T, Fon PN. Oral health status of diabetes mellitus patients in Southwest Cameroon. Odontostomatol Trop. 2015 Jun;38(150):49-57.

13. Thresia CU, Thankappan KR, Nichter M. Smoking cessation and diabetes control in Kerala, India: an urgent need for health education. Health education research https://doi.org/10.1093/her/cypozo

13.The global burden of disease: 2004 update. Geneva, World Health Organization; 2008.

\section{AUTHOR AFFILIATIONS: ( ${ }^{*}$ Corresponding Author)}

1. Intern, Himachal Dental College, Sunder Nagar, H.P., India (https://orcid.org/oooo-ooo1-6655-3634, Preeti Agnihotri, https://orcid.org/oooo-ooo19717-942X, Yashika Sharma) 